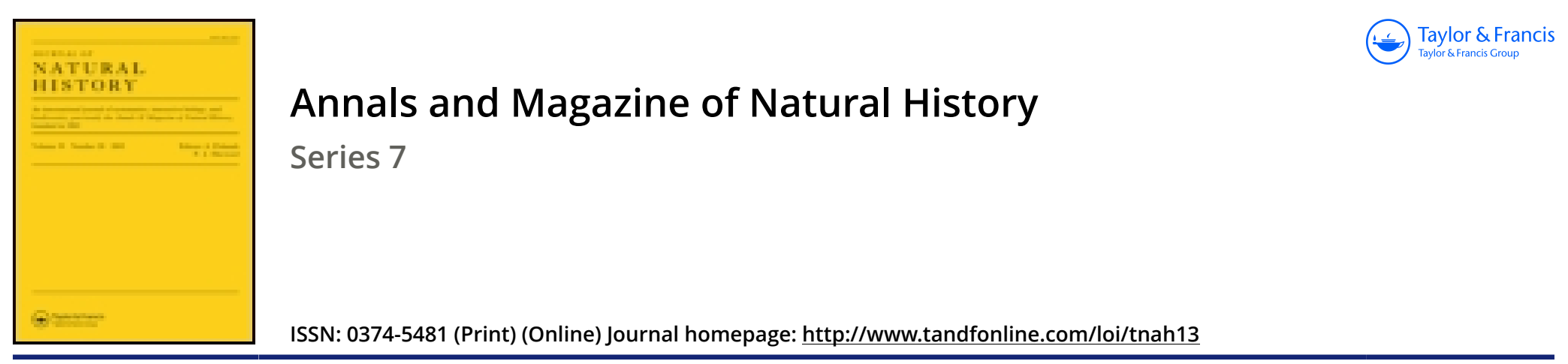

\title{
LIV.-On a new hare from the Transvaal
}

\section{H. Lyster Jameson}

To cite this article: H. Lyster Jameson (1907) LIV.-On a new hare from the Transvaal , Annals and Magazine of Natural History, 20:119, 404-406, DOI: 10.1080/00222930709487358

To link to this article: http://dx.doi.org/10.1080/00222930709487358

册Published online: 29 Sep 2009.

Submit your article to this journal $2 \pi$

Q View related articles $₫$ 
dark line, margined on each side by a series of pale yellow spots, like beads."

According to Moreau, the pale spots bordering the dark undulated stripes may frequently be absent, or in large specimens they may be greyish white in colour and the stripes may be less distinctly marked than in the young.

\section{LIV.-On a new Hare from the Transvaal. By H. Lyster J AMESON.}

IN June of this year I noticed a large grey Pronolagus on the Observatory Kopje adjoining the town of Johannesburg. After some difficulty I succeeded in trapping this specimen, a full-grown and pregnant female, which proved to belong to a hitherto undescribed form. Pending a fuller study of the genus Pronolagus I shall describe this hare as a High-Veld race of Pronolagus Ruddi (Thomas and Schwann, Abstract P. Z. S. no. 18, p. 23, April 25, 1905 ; and P. Z. S. 1905, vol. i. p. 272).

The Witwatersrand Pronolagus is specially interesting because it extends considerably the range of the $P$. Ruddi group westwards, hitherto known only from Zululand and the Eastern Transvaal.

This form differs from the type species (so far as I can gather by comparing it with Thomas's description, for I have not had an opportunity of comparing it with the type) in its generally grey colour, in the dark tail, black for its distal third, in the absence of slaty bases to the fur, and in having black soles to its feet.

\section{Pronolagus Ruddi randensis *, subsp. $n$.}

Size as in $P$. Ruddi (much larger than in $P$. crassicaudatus). Coat harsh, as in $P$. Ruddi. Ground-colour buff, heavily pencilled with black, giving the impression of rather dark grey when seen at a distance. Colour a little lighter on rump. The long stiff hairs are black, with a subterminal buff zone, as in $P$. Ruddi, and are about $18 \mathrm{~mm}$. long. Among these, especially along the back, are a few very long hairs (40 mm. or more), which are white at the base and black distally, sometimes with a subterminal white

* Subspecific name from Rand, popular abbreviation for Witwatersrand, the name of the range of hills on which Johannesburg is situated. 
ring. These hairs give the middle part of the back a particularly dark grey appearance. Wool-hairs buff, without the slaty-orey bases characteristic of $P$. Ruddi.

Under surface buff, passing into grey on the flanks, so that there is no sharp line between back and belly. This gradation is due to the amount of black in the long coarse hairs becoming less towards the ventral surface, until, in the midventral region, these hairs are entirely buff-coloured.

Head bluish grey, with a slight rufous tinge on the forehead. Nape-patch small and inconspicuous, rather more rufous than back. Throat and chest as back. Ears grey, as in $P$. Ruddi, but without the black edge. Limbs buffy rufous, not any lighter towards digits. Soles black.

Tail very large and bushy, about $140 \mathrm{~mm}$. long, including the hairs; dark reddish brown, pencilled with black, at base; distal third of tail black.

Stcull as in $P$. Ruddi, but slightly larger and rather narrower in the nasal region. The palatal foramina are not quite so much narrowed posteriorly, their inwardly directed edges, so conspicuous in $P$. Ruddi, being reduced to mere narrowed ridges of bone, so that the walls of the nasal chamber are exposed, as in P. crassicaudatus. The notch in the incisors is more distinct than in Thomas's figure of the skull of P. Ruddi (P. Z. S. 1905, i. pl. xvi. fig. 4). 'The upper molars have the uncrenulated anterior enamel-wall of the posterior lamina extending considerably less than halfway across the tooth, thus presenting conditions intermediate between $P$. Ruddi and P. crassicaudatus. The anterior lower premolars also show an intermediate condition, their anterior walls having a single notch on the left side and a double one on the right.

Dimensions of the type (measured in the flesh) :-

Head and body $480 \mathrm{~mm}$; tail 110 ; hind foot 100 ; ear 97 ; ear-opening 87.

Skull dimensions: greatest length 94 ; basilar length 74 ; zy gomatic breadth 41 ; nasals $47 \times 20$; interorbital breadth 18 , intertemporal breadth 15 ; palatal foramina $29 \times 8.5$; palatal bridge 10 ; diastema 32.5 ; greatest breadth of nasal region, at level of anterior upper premolar, 23. For measurements of $P$. Ruddi see Thomas and Schwann (loc. cit.) ; for dimensions of two races of $P$. crassicaudatus see Thomas, Ann. \& Mag. Nat. Hist. (7) vol. x. pp. 244-246 (1902).

Hab. Witwatersrand Range, Transvaal.

Type. Female. No. 108 in my collection. Observatory, Johannesburg, $5900 \mathrm{ft}$., 25th June, 1907.

In habits this hare resembles $P$.crassicaudatus and $P . R u d d i$. 
It frequents the stony kopjes of the Witwatersrand, spending the day in holes under rocks and boulders, and coming out to feed at dusk. I have only once found it lying out in the daytime.

Like other Pronolagi, it frequently returns to the same spot to defæecate ; hence its presence in a locality can often be detected by the piles of droppings on the hill-sides. It is a very retiring species, and seems little known among local sportsmen, although it occurs right, up to the outskirts of Johannesburg.

Its short ears, heary build, and general pose at once recall the European rabbit. It is very fleet on foot; in fact, the "red hare" (a collective name for the members of the genus Pronolagus) is regarded by sportsmen as the fastest of the South-African hares.

The uterus of the type specimen contained a single large leveret.

University College, Johannesburg, September 1907.

\section{LV.-On a new Dormouse from Asia Minor, with Remarks on the Subgenus "Dryomys." By OldField Thomas.}

IN $1906^{*}$ I formed a special subgenus to contain the dormouse previously known as Eliomys nitedula, Pallas (syn. E.dryas, Schr.), and gave it the name of Dryomys; but I now find that this name is preoccupied $\dagger$, and would propose to replace it by Dyromys, an anagram of the same word.

Since I formed the subgenus there has been discovered the large but nearly related Central-Asian species to which I applied the specific name angelus, and Mr. Gerrit Miller has drawn my attention to additional points of distinction between

* P. Z. S. 1906, ii. p. 348.

† "Dryomys parvulus, Tschudi, Fauna Peruana, p. 179, lam. xiii. fig. l." Philippi, An. Mus. Chile, Murideos de Chile, p. 20 (1900).

Although this is, no doubt, merely an erroneous rendering of Drymomys, yet, as it occurs with a specific name attached and a reference both to a description and figure, it seems to be technically too valid as a name to be used again for another animal.

Another of my generic names, Neotomys, was used as a misprint for Nectomys by Wallace some years before I published it, but there the misprinted term was without any mention of a species or reference to a description, and consequently, viewed simply by itself, was a mere nomen nudum, which was not the case with Philippi's Dryomys. 